\title{
Electronic Word of Mouth Source (Tourism Social Media) towards Domestic Tourists' Attitudes
}

\author{
Galih Abdul Fatah Maulani, Nizar Alam Hamdani, Asri Solihat, Intan Permana \\ \{galihafm@uniga.ac.id, nizar hamdani@uniga.ac.id, asrisolihat@uniga.ac.id , \\ intanpermana@uniga.ac.id \}
}

Universitas Garut, Indonesia, Jalan Jati No. 42 B Tarogong Garut, Indonesia

\begin{abstract}
The significant growth of social media users makes social media an effective and efficient marketing weapon for all types of businesses, including those in the tourism sector. This study examines the attitudes of domestic tourists towards Electronic Word of Mouth (EWOM) sources, especially Instagram accounts advertising tourism services. Data collection was performed using an online survey on 116 respondents. The results revealed that there was a significant positive relationship between domestic tourists' trust and EWOM. Therefore, it is necessary for a company or business owners to build consumer trust in their EWOM sources.
\end{abstract}

Keywords: electronic word of mouth, social media, marketing strategy, tourism.

\section{Introduction}

Today's digital age demands business entities, including ones in tourism sector, to adapt their company's strategies to more effective and efficient and unique community access needs [1] to improve their business performance [2]. In Indonesia, tourism is one of interesting research subjects and has been one of the state's leading sectors.

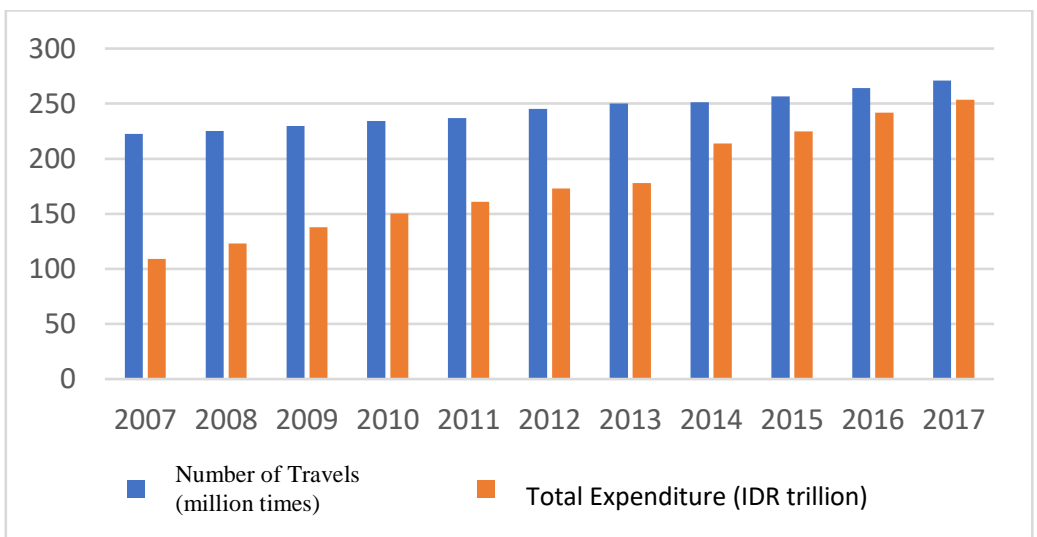

Fig 1. Number of Domestic Tourists' Travels and Expenditure in 2010-2017 [3] 
Indonesian domestic tourists' total expenditure in 2017 was IDR 253.45 trillion, an increase of $4.87 \%$ from the previous year. The number of their travels in 2017 was 270.82 million times, an increase of 2.45 that in the previous year [3].

The development of several businesses, especially SMEs, would be better with help of internetbased information services on social media [4] thanks to the ever-increasing number of social media users [5].

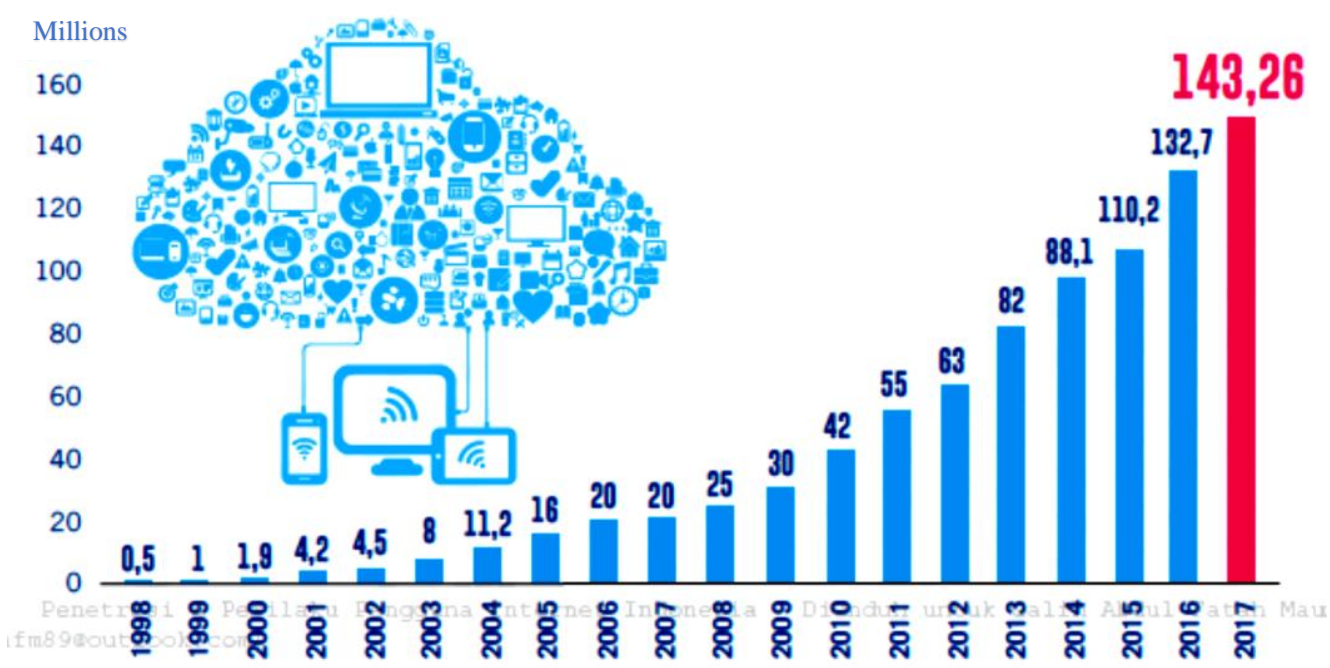

Fig 2. Growth of Indonesian Internet Users

Data from the Association of Indonesian Internet Providers shows that Indonesian Internet users increase year in year out. In 2017, Internet users in Indonesia reach 143.26 million. About $87.13 \%$ of them access information on social media [5], including ones promoting tourism services.

In the scientific development of marketing management, Word of Mouth (WOM) has received much attention from many researchers [6]. WOM has been reported to have significant influence on consumer behaviors [4], [6], [7].

The use WOM is no longer restricted to conventional communication. As Internet advances, WOM shifts to electronic Word of Mouth (eWOM) as a means of customer communication in cyberspace [8].

In many studies on tourism industries, eWOM has been reported to be very influential [9]. Many of the previous studies focused on the relationship between types of travel, tourist characteristics, and information seeking behavior; some other focused on user perceptions, information use and marketing [10]. However, the focus of eWOM studies are rather limited to the issue of customer behaviors, especially the attitude of domestic tourists[9][11]. The present study is mainly aimed at providing empirical evidence of the relationship between eWOM and domestic tourists' attitude in Garut, Indonesia. 


\section{Theoretical Background}

\subsection{Electronic word of mouth}

Electronic word of mouth (eWOM) is one of the marketing strategies through communication that basically convey messages and impressions about a product or service in the form of comments on a web-based platform [4]. Besides, eWOM is an informal evaluation of goods and services done by all parties [12], which can determine consumer behaviors and purchase intention [13].

In the tourism industry, eWOM plays an important role in determining costumer trust [9], [14]. Prospective tourists will refer to eWOM in the decision-making process [15].

Previous studies suggests that eWOM has two dimensions, namely product information and emotion [4][16][17][18]. Indicators used to measure eWOM includes intensity, content, platform assistance, valance of opinion, venting negative feelings, concern for the others, social benefits, positive self enhancement, economic incentives, helping the company, advice seeking [4], [7], [8], [19]-[21].

\subsection{Domestic Tourists' Attitudes}

The concept of attitude plays a central role in the scientific inquiry to understand human behaviors. Studies on attitudes emerge as important parts of social sciences [22]. The tourists' attitudes refers to their overall evaluation towards comments [9]. Tourists' attitudes towards comments have been defined as the extent to which they conduct a favorable or unfavorable evaluation or assessment [8][6], [23].

Tourists' attitudes are deemed to play a major role in determining consumer behaviors, which are established in their previous experience [24]. Their attitudes consist of three elements: belief (cognitive), involving one's knowledge of a particular object, emotion (affective) which refers to individual feeling about stimuli based on their belief, and intention (conative) which refers to how ones respond to an object based on their emotion and belief [25].

\section{Methodology}

This study was conducted using a quantitative approach. The sample respondents were 116 domestic tourists in Garut who regularly searched information using social media. These samples were selected using a random sampling technique. Data were analyzed using SMARTPLS.

The following six indicators were used to measure eWOM:[11][9]

1. $\mathrm{X} 1=\mathrm{I}$ Often read other tourists online travel reviews to know what destinations make good impressions on others.

2. $\mathrm{X} 2$ = To make sure I choose the right destination, I often read other tourists' online travel reviews

3. $\mathrm{X} 3$ = I often consult other tourists' online travel reviews to help choose an attractive destination 
4. $\mathrm{X} 4=\mathrm{I}$ frequently gather information from tourist' online travel reviews before I travel to a certain destination

5. X5 = If I don't read tourists' online review when I travel a destination, I Worry about my Decision.

6. X6 = When I Travel to a destination, tourist online travel reviews make me confident in travelling to the destination.

Tourists' attitudes were measured using three indicators; namely, $\mathrm{Y} 1=$ honesty; Y2 = competence; Y3 = benevolence [26][27].

\section{Result and Discussion}

Figure 3 illustrates the PLS modeling.

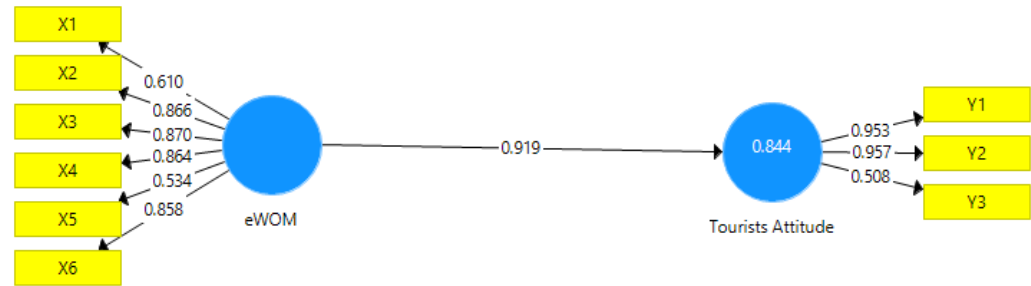

Fig 3. Result of PLS analysis

As shown in Figure 3, each indicator has a loading value. Indicators are stated valid provided that their loading values are $>0.6$. The PLS Algorithm shows that the loading values of X5 and Y3 were below 0.6 . These indicators were then removed from the model.

\section{Construct Reliability and Validity}

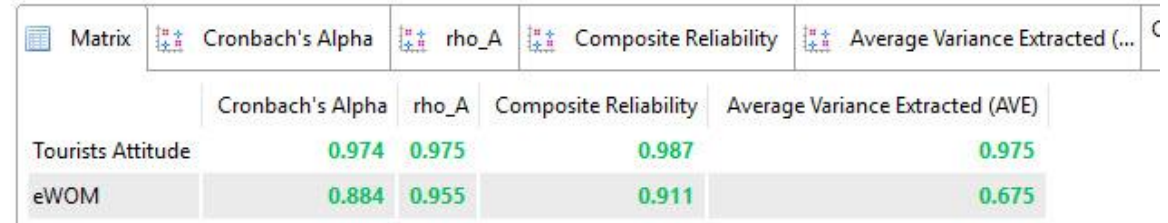

Fig 4. Construct Reliability and Validity

The validity of the variables can be determined by the Average Variance Extracted (AVE). The suggested AVE value is above 0.5. Figure 4 shows that the AVE value of both variables eWOM and Tourists' Attitudes have met this requirement, meaning that they have convergent validity. The variable validity can be determined by the Composite Reliability. The suggested value is above 0.7 . Figure 4 shows that both variables were reliable. 


\begin{tabular}{|c|c|c|c|c|}
\hline \multirow[t]{2}{*}{ Matrix } & 提革 & R Square & \multicolumn{2}{|c|}{ 㩲 $\mathrm{H}$ S Square Adjusted } \\
\hline & & & R Square & R Square Adjus... \\
\hline \multicolumn{2}{|c|}{ Tourists Attitude } & & 0.838 & 0.833 \\
\hline
\end{tabular}

Fig 5. R Square

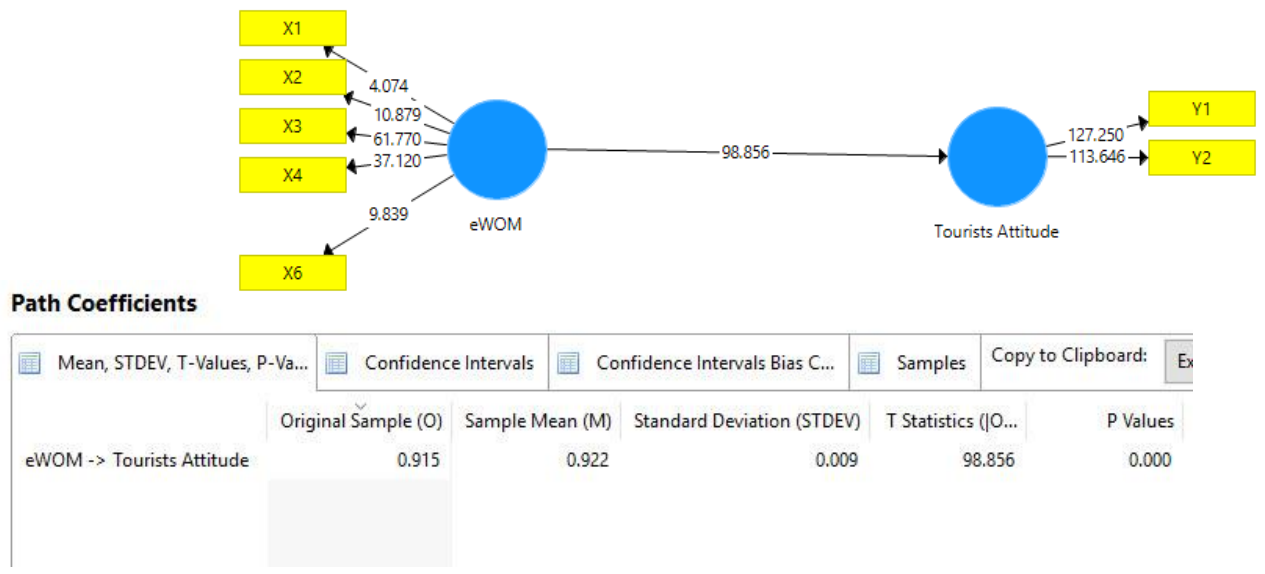

Fig 6. Result of Bootstrapping

Figure 5 shows that eWOM contributes to tourists' attitudes as much as $83 \%$. In addition, the path coefficient in Figure 6 shows that the relationship between eWOM (X) and tourists' attitudes (Y) was significant with the T-Statistics of $98.856(>1,66)$. Since original sample estimate value was positive, the relationship between two variables was also positive.

\section{Conclusion}

This study has found that there was a significant positive relationship between eWOM and domestic tourists' attitudes, meaning that eWOM plays an important role in determining domestic tourists' behaviors. It is necessary for tourist destination managers to take into account the fact that information posted on a particular online community is a form of eWOM that tourists may use as a reference for their decision making.

\section{References}

[1] N. A. Hamdani, "Building Knowledge Creation For Making Business Competition Atmosphere in SME of Batik," Manag. Sci. Lett., vol. 8, pp. 667-676, 2018.

[2] N. A. Hamdani, T. Susanto, and G. Abdul Fatah Maulani, "Framework of Architectural Marketing Capabilities in Regional Development Bank," Int. J. Eng. Technol., vol. 7, no. 3.25, pp. 166-169, 2018.

[3] Barudin, I. A. Fitriyani, and D. Indriati, “Kajian Data Pasar Wisatawan Nusantara,” p. 210, 2017.

[4] N. A. Hamdani, G. Abdul, and F. Maulani, "The influence of E-WOM on purchase intentions in local culinary business sector," vol. 7, pp. 246-250, 2018.

[5] APJII, Penetrasi \& Perilaku Pengguna Internet Indonesia, vol. 2018, no. 31 August 2018. 2017.

[6] N. Putu Yudi Setiawan, Eka Afnan Troena, Armanu, "the Effect of Destination Image on 
Authenticity and Loyalty," Eur. J. Bus. Manag., vol. 4, no. 3, pp. 95-118, 2013.

[7] Y.C. Wang, "A study on the influence of electronic word of mouth and the image of gastronomy tourism on the intentions of tourists visiting Macau," Tourism, vol. 63, no. 1, pp. 67-80, 2015.

[8] T. Hennig-Thurau, K. P. Gwinner, G. Walsh, and D. D. Gremler, "Electronic word-of-mouth via consumer-opinion platforms: What motivates consumers to articulate themselves on the Internet?," J. Interact. Mark., vol. 18, no. 1, pp. 38-52, 2004.

[9] H. Zarrad and M. Debabi, "Analyzing the Effect of Electronic Word of Mouth on Tourists , attitude toward Destination and Travel Intention," Int. Res. J. Soc. Sci., vol. 4, no. 4, pp. 53-60, 2015.

[10] L. Murphy, G. Mascardo, and P. Benckendorff, "Exploring word-of-mouth influences on travel decisions : friends and relatives vs . other travellers," vol. 31, pp. 517-527, 2007.

[11] M. Reza, S. Shekarchizadeh, and N. Samiei, "Procedia Computer Electronic word-of-mouth: challenges and opportunities," Procedia Comput. Sci., vol. 3, pp. 42-46, 2011.

[12] J. H. Chang and S. H. Wang, "Different levels of destination expectation: The effects of online advertising and electronic word-of-mouth," Telemat. Informatics, vol. 36, no. March 2018, pp. 27-38, 2019.

[13] R. I. E. D. El-Baz, "The effect of electronic word of mouth on brand image and purchase intention: An empirical study in the automobile industry in Iran," Mark. Intell. Plan., vol. 32, no. 4, pp. 413-435, 2014.

[14] Q. Luo and D. Zhong, "Using social network analysis to explain communication characteristics of travel-related electronic word-of-mouth on social networking sites," Tour. Manag., vol. 46, pp. 274-282, 2015.

[15] J. Goldenberg, B. Libai, and E. Muller, "List of literature 2010," Mark. Lett., vol. 12, no. 3, pp. 211-223, 2001.

[16] C. M. K. Cheung and D. R. Thadani, "The State of Electronic Word-Of-Mouth Research: A Literature Analysis," PACIS 2010 Proc., p. 151, 2010.

[17] F. Xiaorong, Z. Bin, X. Qinghong, X. Liuli, and C. Yu, "Impact of Quantity and Timeliness of EWOM Information on Consumer's Online Purchase Intention under C2C Environment," Asian J. Bus. Res., vol. 1, no. 2, pp. 37-52, 2011.

[18] C. Achar, J. So, N. Agrawal, and A. Duhachek, "What we feel and why we buy: The influence of emotions on consumer decision-making," Curr. Opin. Psychol., vol. 10, pp. 166-170, 2016.

[19] I. Goyette, L. Ricard, and J. Bergeron, "e-WOM Scale : Word-of-Mouth Measurement Scale for e-Services Context *," vol. 23, pp. 5-23, 2010.

[20] A. Akyüz, "Determinant Factors Influencing eWOM," Mediterr. J. Soc. Sci., vol. 4, no. 11, pp. 159-166, 2013.

[21] N. Kaijasilta, "The Conceptualization of Electronic Word-of-Mouth (EWOM) and Company Practices to Monitor, Encourage, and Commit to EWOM - a Service Industry Perspective," Aalto University School of Business, 2013.

[22] S. J. Kraus, "Attitudes and the Prediction of Behavior: A Meta-Analysis of the Empirical Literature," Personal. Soc. Psychol. Bull., vol. 21, no. 1, pp. 58-75, 2008.

[23] S. Naurin, A. Assistant, M. Laroche, and R. Bank, "Analyzing electronic word of mouth : A social commerce construct," Int. J. Inf. Manage., vol. 37, pp. 202-213, 2017.

[24] M. H. Hanafiah, M. R. Jamaluddin, and M. I. Zulkifly, "Local Community Attitude and Support towards Tourism Development in Tioman Island, Malaysia," Procedia - Soc. Behav. Sci., vol. 105, pp. 792-800, 2013.

[25] L. C. Torres Chavarria and P. Phakdee-auksorn, "Understanding international tourists' attitudes towards street food in Phuket, Thailand," Tour. Manag. Perspect., vol. 21, pp. 66-73, 2017.

[26] R. Ladhari and M. Michaud, "International Journal of Hospitality Management eWOM effects on hotel booking intentions, attitudes, trust, and website perceptions," Int. J. Hosp. Manag., vol. 46, pp. 36-45, 2015.

[27] T. Wang, R. K. Yeh, C. Chen, and Z. Tsydypov, "Telematics and Informatics What drives electronic word-of-mouth on social networking sites? Perspectives of social capital and selfdetermination," vol. 33, pp. 1034-1047, 2016. 